\title{
Quantitative Estimation of Minerals, Secondary Metabolites and GC-MS Profile of Chomelia asiatica Linn. Root
}

\author{
N. Anjanadevi* \\ PG and Research Department of Botany, Vellalar College for Women, Erode- 638012, Tamil Nadu, India; \\ anjananatesan@gmail.com
}

\begin{abstract}
The ethanolic root extract of Chomelia asiatica was found to contain macroelements such as total nitrogen, phosphorus, potassium, calcium, sodium and magnesium contents. Total nitrogen content was recorded maximum. Microelements test revealed the presence of iron content only. Manganese, zinc, selenium, cobalt and boron were not recorded. Secondary metabolites such as total phenolic substance, tannin content and total flavonoid substance were recorded during quantitative estimation. The phenolic substance was found to be elevated. Flavonoid and tannin substances were less than the phenol compounds. Analysis through Gas Chromatograph-Mass Spectrometry identified 19 phytocomponents. 2',4',6'-Trideutero2,4,6-trimethylbenzaldehyde was found to be maximum with 8.63 peak area percentage at 31.40 retention time.
\end{abstract}

Keywords: Chomelia, GC-MS Analysis, Minerals, Secondary Metabolites

\section{Introduction}

The quest for good health and immortality has been a continuous human endeavour since the beginning of civilization throughout the World. In all ages and civilizations, man's dependence on plants for food and medicine was well chronicled. Plants have persistent to participate a superseding role in preserving and safeguarding the human health since prehistoric times. Human beings are suffering from illness and diseases. The search for relief from ailments prompted them to explore their surroundings for a remedy. As a result they started to use various natural hidden agents of the plants, as they were being forefront. Majority of plants are collected from the forests that are the principal repositories of herbal plants. The herbal medicines are beginning to find their due place and recognition in society, which they rightly deserved due to the presence of array of chemical compound [1, $2]$. Hence, the current research was taken up to estimate minerals, secondarily considered metabolic substances and GS-MS profiling in the root of a sporadic medicinal plant, Chomelia asiatica (L.) Okze, as it is traditionally used for skin diseases [3-5] by the folk healers of Kanjamalai.

\section{Materials and Methods}

\subsection{Identification, Authentication and Seed Collection}

A sporadic plant, Chomelia asiatica available at Kanjamalai, Salem district claimed to cure skin diseases was selected for the present investigation and it was identified using Floras and legitimated by Botanical Survey of India, Coimbatore. Matured seeds were collected and allowed to germinate and continued to grow in a pot up to one year. At the closing stages of the year roots were unruffled, shadow desiccated and powered and used for the analysis of macro and microelements, secondary metabolites and subjected to GC-MS analysis. 


\subsection{Estimation of Minerals}

\subsubsection{Total Nitrogen}

Total nitrogen content [11] was estimated using the microkjeldahl method that mentioned below.

Digestion Procedure- Fresh materials were oven dried and ground to 40-mesh size. The powdered substance was again at $70^{\circ} \mathrm{C}$ oven dried before digestion. $100 \mathrm{mg}$ of oven dried powdered material was taken in a microkjeldahl flask. To that $100 \mathrm{mg}$ of catalyst (copper sulphate:potassium sulphate:selenium dioxide 11:9:1), $4 \mathrm{ml}$ of Conc. $\mathrm{H}_{2} \mathrm{SO}_{4}$ and $4 \mathrm{ml}$ of hydrogen peroxide were added. Digestion was carried out by keeping the sample on a hot plate until a clear colourless solution obtained. After digestion, the clear colourless solution was prepared up to $25 \mathrm{ml}$ using distilled water.

Estimation- Aliquots of the digest in $5 \mathrm{ml}$ were taken into the distillation unit and $10 \mathrm{ml}$. of $40 \% \mathrm{NaOH}$ was added. Distillation was carried out for 20 minutes. $5 \mathrm{ml}$ of boric acid, indicator mixture, was taken in a conical flask and kept at the receiving end of the distillation unit. The ammonia liberated was absorbed by the boric acid indicator mixture kept in conical flask. The indicator solution was turned into pink in the beginning and became green at the end of complete distillation. The content (green in colour) was titrated against $\mathrm{N} / 100 \mathrm{HCl}$, until pink colour reappeared. The quantity of nitrogen available in the test material was calculated considering that $1 \mathrm{ml}$ of N/100 $\mathrm{HCl}=0.14 \mathrm{mg}$ of nitrogen.

The other macro and micro nutrient analysis were carried out using Atomic Absorption Spectrophotometer (Model ECIL AAS 4127). The contents of Phosphorus $(\mathrm{P})$, Potassium $(\mathrm{K})$, Sodium (Na), Manganese (Mn), Magnesium (Mg), Iron (Fe), Zinc (Zn), Selenium (Se), Cobalt (Co) and Boron (B) Calcium (Ca), were analyzed with the respective cathode lamp [17].

\subsubsection{Quantification of Phenolic Substance and Tannin Substance}

Aliquots in ten microlitres $(10 \mathrm{mg} / 2 \mathrm{ml})$ were taken in glass tubes. Using distilled water, the aliquots were prepared up to the quantity of 1 millilitre. Further added 0.5 millilitre of Folin-Ciocalteau phenol substance and sodium carbonate solution (20\%) of 2.5 millilitre in each tube one after the other. The rejoinder potion was allowed to vortex. At once the glass tubes were positioned in gloomy place for 40 minutes and the absorbance was read at $725 \mathrm{~nm}$ against the reagent blank. The study was worked out in triplicate and the outcome was uttered as tannic acid equivalent [15].

The tannin substance was predictable after treating with the chemical polyvinyl polypyrrolidone [16] using the same extract. Weighed 100 milligram of Polyvinyl polypyrrolidone was taken in a $100 \times 12$ millimeter glass tube and supplemented with 1 millilitre distilled water and $1 \mathrm{ml}$ of the test extract. The substance was vortexed and set aside incessant in the test tube at $4^{\circ} \mathrm{C}$ for $4 \mathrm{hrs}$. Then the test extract was subjected to centrifugal force (at $3000 \mathrm{rpm}$ for ten minutes at laboratory warmth) and the top solution leaving the sediment was gathered. This top solution has only plain phenolics other than tannin substance (In the company of the chemical polyvinyl polypyrrolidone, the tannin substance would have been precipitated). The phenolic substance of the top solution was intended and uttered on a dry matter basis as the substance of tannin less phenolics. On getting above domino effect, the tannin substance of the test material was intended as below:

Tannin (\%) = the full quantity phenolic content (\%) tannin less phenolic content (\%)

\subsubsection{Quantification of Flavonoids}

Aliquot (appropriately $10 \mathrm{mg} / 2 \mathrm{ml}$ ) of diluted sample solution in $0.5 \mathrm{ml}$ was assorted with two $\mathrm{ml}$ of purified water and consequently with $0.15 \mathrm{ml}$ of five per cent sodium nitrite solution. After 6 minutes, $0.15 \mathrm{ml}$ of ten per cent aluminium chloride solution was supplemented. This was allowed to set for 6 minutes and afterward $2 \mathrm{ml}$ of four per cent sodium hydroxide solution was supplemented to the mixture. To fetch the final quantity to five $\mathrm{ml}$, subsequently, glass distilled water was poured gently. After that the concoction was methodically assorted and allowed to position for an additional fifteen minutes. The blend was resoluted at 510 nanometer against water as blank. The outcomes were expressed as rutin equivalent [18].

\subsection{Gas Chromatography/Mass Spectrometry Technique}

C. asiatica root ethanol haul out at $2 \mu \mathrm{l}$ was subjected to GC/MS technique.

\subsubsection{Instrumentation Technique and Conditions of Chromatography}

Using Gas chromatography clarus 500 Perkin Elmer system comprise a AOC-20i auto sampler, GC-MS investigation 
was conceded. Gas Chromatograph interfaced to a Mass Spectrometer device is working under following environment: Column Elite-1 fused silica capillary column (30 $\times 0.25 \mathrm{~mm}$ ID $\times 1 \mathrm{EM}$ df, composed of $100 \%$ Dimethyl poly siloxane), functioning in electron force sort at 70 eV. Carrier gas Helium (99.999\%) at a steady flow of $1 \mathrm{ml} /$ minute was used. An injection quantity of $0.5 \mathrm{EI}$ was set off (10:1 split ratio. The temperature of the injector and ion-source was respectively at $250^{\circ} \mathrm{C}$ and at $280^{\circ} \mathrm{C}$. The temperature of oven was considered from $110^{\circ} \mathrm{C}$ (isothermal for 2 minutes), with an enhance of $10^{\circ} \mathrm{C} /$ minute, up to $200^{\circ} \mathrm{C}$ /minute, then $5^{\circ} \mathrm{C} /$ minute up to $280^{\circ} \mathrm{C} /$ minute and concluding at $280^{\circ} \mathrm{C}$ with a 9 minutes isothermal conditions. At $70 \mathrm{eV}$, mass spectra were resolved with fragments from 40 to 550 Dalton and a scan gap of 0.5 second [12].

\section{Experimental Results and Discussion}

Macroelements contents such as total nitrogen, phosphorus, potassium, calcium, sodium and magnesium were found to be present in the root sample of $C$. asiatica (Table 1). The root sample analysis exhibited the presence of iron as an only microelement. Other minerals were found to be absent. Nitrogen is a fundamental component of protein and nucleic acids and many other organic molecules, which play an imperative role in plant life. Being essential for the construction of protoplasm, which is predominantly proteinaceous, the insufficiency of nitrogen inhibits cell division and cell magnification. In the present study, the nitrogen content was maximum in the root sample. Similar information was reported in Faramea occidentalis [14] and in Pavetta indica [13]. Phosphorus is an indispensable constituent of lipoprotein membranes of the cell nucleoproteins, organic molecules and many coenzymes. Calcium is crucial for

Table 1. Analysis revealed the presence of macro and microelements in the root sample of C. asiatica

\begin{tabular}{|c|c|c|c|c|}
\hline S. No. & Macroelements & $\begin{array}{c}\mathbf{m g} / \mathbf{1 0 0 g m} \\
\text { root }\end{array}$ & Microelements & $\begin{array}{c}\mathrm{mg} / \mathbf{1 0 0 g m} \\
\text { root }\end{array}$ \\
\hline 1 & Total Nitrogen & 1025.0 & Iron & 58.6 \\
\hline 2 & Phosphorus & 408.0 & Manganese & - \\
\hline 3 & Potassium & 134.0 & Zinc & - \\
\hline 4 & Calcium & 159.0 & Selenium & - \\
\hline 5 & Sodium & 28.9 & Cobalt & - \\
\hline 6 & Magnesium & 56.7 & Boron & - \\
\hline
\end{tabular}

neuromuscular mechanism [3]. Many enzymes would function efficiently in the presence of inorganic activators like $\mathrm{Ca++}, \mathrm{Mn}, \mathrm{Mg}$ and $\mathrm{Cl}$, as they actively take part in the enzyme substrate complex [6].

The root sample contains phenolic substance, tannins and flavonoid substance (Table 2). Phenolic substance is of vast significance as cellular sustaining resources. They figure a central and vital part of cell wall structures. By means of this formulation, plants become modified to terrestrial life by edifying inflexible organs [7]. The occurrence and amount of phenolics in Rubiaceae plants was well documented by many scientists [8-10]. Tannins, the plant polyphenols are usually soluble in water and precipitate protein from aqueous solutions, located in vacuoles. This cluster of compound have established an enormous deal of concentration in current years, as it is optional that the utilization of tannin include beverages; particularly, green tea and red wines can alleviate otherwise thwart a diversity of illness. Flavonoids are well known phytochemicals having sound biological effects such as free radical scavenge activity, intonation of enzymatic activity and prospective utility as antibiotics and anti-inflammatory agents.

Table 2. Phytochemicals in ethanol root extract of $C$. asiatica

\begin{tabular}{|c|c|c|c|}
\hline $\begin{array}{c}\text { Test } \\
\text { material }\end{array}$ & $\begin{array}{c}\text { Total phenolic } \\
\text { content (mg TAE/g } \\
\text { root extract) }{ }^{*}\end{array}$ & $\begin{array}{c}\text { Tannin content } \\
(\text { mgTAE } / g \\
\text { extract })^{*}\end{array}$ & $\begin{array}{c}\text { Total flavonoid } \\
\text { content (mg RE/g } \\
\text { root extract) }{ }^{\#}\end{array}$ \\
\hline Root & $75.3 \pm 3.1$ & $55.2 \pm 2.4$ & $09.1 \pm 0.1$ \\
\hline
\end{tabular}

Values are given in Mean \pm SE based on triplicates maintained in each test.

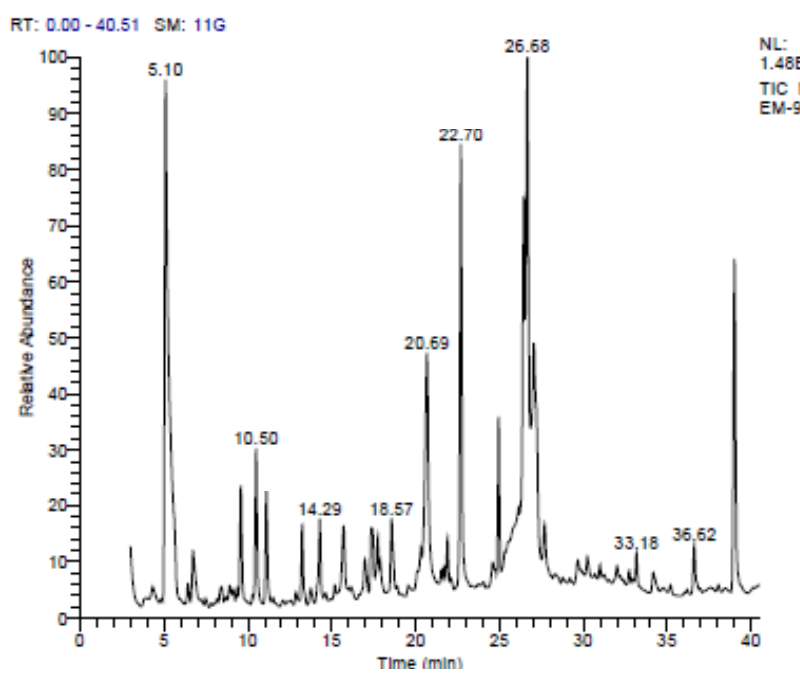

Figure 1. Chomelia asiatica root screened phytochemicals through GC/MS chromatogram. 
Table 3. Phytochemicals documented from the root of Chomelia asiatica through GC-MS technique

\begin{tabular}{|c|c|c|c|c|c|}
\hline Sl. No. & Retention time & Chemical compounds & $\begin{array}{c}\text { Molecular Formula } \\
\text { of Chemicals }\end{array}$ & Molecular Weight & $\begin{array}{c}\text { Peak } \\
\text { Area }(\%)\end{array}$ \\
\hline 1 & 3.47 & 11-Hydroxyalliacolide & $\mathrm{C}_{15} \mathrm{H}_{22} \mathrm{O}_{5}$ & 282 & 2.94 \\
\hline 2 & 5.10 & $\begin{array}{l}\text { (R)-2-Amino-3-methoxypropan-1-ol } \\
\text { hydrochloride dl-Serine (CAS) }\end{array}$ & $\mathrm{C}_{4} \mathrm{H}_{11} \mathrm{NO}_{2}$ & 105 & 2.40 \\
\hline 3 & 10.50 & Hept-1-en-3-on & $\mathrm{C}_{7} \mathrm{H}_{12} \mathrm{O}$ & 112 & 1.92 \\
\hline 4 & 14.29 & Tetracosamethyl cyclododecasiloxane & $\mathrm{C}_{24} \mathrm{H}_{72} \mathrm{O}_{12} \mathrm{Si}_{12}$ & 888 & 1.82 \\
\hline 5 & 18.57 & Tetradecanoic acid (CAS) & $\mathrm{C}_{14} \mathrm{H}_{28} \mathrm{O}_{2}$ & 228 & 1.68 \\
\hline 6 & 20.69 & $\begin{array}{l}\text { 1-oxa-4-methoxy-5-hydroxy-5-(2- } \\
\text { phenylethylcarbonyl) }\end{array}$ & $\mathrm{C}_{14} \mathrm{H}_{14} \mathrm{O}_{4}$ & 245 & 1.95 \\
\hline 7 & 22.70 & $\begin{array}{l}\text { 1-(2-naphthyl)methylene-2-(phenoxycarbonyl)- } \\
\text { Hydrazine, }\end{array}$ & $\mathrm{C}_{18} \mathrm{H}_{14} \mathrm{~N}_{2} \mathrm{O}_{2}$ & 290 & 2.04 \\
\hline 8 & 25.88 & Arachidonoyl ethanolamide & $\mathrm{C}_{22} \mathrm{H}_{37} \mathrm{NO}_{2}$ & 347 & 2.28 \\
\hline 9 & 26.68 & 2-(dimethyl amino)methyl]aniline & $\mathrm{C}_{23} \mathrm{H}_{24} \mathrm{~N}_{2} \mathrm{~S}$ & 360 & 3.68 \\
\hline 10 & 28.94 & 2-Methyl-2-phenylbutylamine & $\mathrm{C}_{11} \mathrm{H}_{17} \mathrm{~N}$ & 163 & 2.54 \\
\hline 11 & 29.45 & Hexanedinitrile, 2-methyl- (CAS) & $\mathrm{C}_{7} \mathrm{H}_{10} \mathrm{~N}_{2}$ & 122 & 3.13 \\
\hline 12 & 29.81 & Cyclopentene & $\mathrm{C}_{24} \mathrm{H}_{24} \mathrm{O}_{4}$ & 376 & 1.92 \\
\hline 13 & 30.98 & 2-Ethyl-1-dodecanol & $\mathrm{C}_{14} \mathrm{H}_{30} \mathrm{O}$ & 214 & 3.60 \\
\hline 14 & 31.40 & 2,4',6'-Trideutero-2,4,6-trimethylbenzaldehyde & $\mathrm{C}_{10} \mathrm{H}_{9} \mathrm{D}_{3} \mathrm{O}$ & 148 & 8.63 \\
\hline 15 & 32.22 & 2-hexanoic acid, ethyl ester & $\mathrm{C}_{19} \mathrm{H}_{28} \mathrm{O}_{4} \mathrm{Si}$ & 348 & 4.10 \\
\hline 16 & 33.16 & (-)-2á-Hydroxy-9-oxoverrucosane & $\mathrm{C}_{20} \mathrm{H}_{32} \mathrm{O}_{2}$ & 304 & 3.51 \\
\hline 17 & 36.62 & $\begin{array}{l}\text { 4,5-Dicyano-1-methyl 2-(3-nitrophenyl) } \\
\text { imidazole }\end{array}$ & $\mathrm{C}_{12} \mathrm{H}_{7} \mathrm{~N}_{5} \mathrm{O}_{2}$ & 253 & 2.75 \\
\hline 18 & 37.19 & à-d-Xylopyranoside & $\mathrm{C}_{30} \mathrm{H}_{51} \mathrm{~B}_{3} \mathrm{O}_{5}$ & 524 & 3.88 \\
\hline 19 & 37.39 & Triphenyleno[2,3-b]thiophene-9,13-dione & $\mathrm{C}_{20} \mathrm{H}_{10} \mathrm{O}_{2} \mathrm{~S}$ & 314 & 4.07 \\
\hline
\end{tabular}

GC-MS Technique: The components recognized by this study in the root sample of Chomelia asiatica are accessible in the Table 3 with their molecular formula of chemicals, molecular weight of chemicals, retention time and percentage of area of peak. The chromatogram $C$. asiatica depicted 19 peaks representing the occurrence of 19 phytocomponents (Figure 1). 19 phytoconstituents were identified and deep rooted based on their characterization and assessment with the mass spectra of the chemical constituent listed in the National Institute Standard and Technology library. 2,4,6-trideutero,2,4,6trimethylbenzaldehyde is the major component found in the root sample of C.asiatica. The compounds are grouped as aliphatic, aldehyde, sugars, alcohols, ketone, fatty acid, terpenoids, phenols, esters and tocopherol. The predicted activities of the components are wound healing, antimicrobial, antiinflammatory, antianginal and antiepileptic activities.

\section{Conclusion}

Estimation of minerals and secondary metabolites in the root samples of $C$. asiatica authenticated its therapeutic value. The secondary metabolites, microelements and macroelements of this sporadic medicinal plant are good candidates for drug formulation that may have more biological friendliness than synthetic drugs. The phytocomponents identified through GC-MS chromatogram have further strengthened this view, which may pave the way to integrate these phytocomponents in traditional as well as in modern system of medicines.

\section{Acknowledgement}

University Grants Commission, SERO, Hyderabad and New Delhi are gratefully acknowledged for the financial assistance. I record my sincere thanks to our madam Principal Dr. (Mrs.) 
D. Kamalaveni for her encouragement and cooperation in applying and completing the Minor Research Project.

\section{References}

1. Ayyanar M, Ignacimuthu S. Herbal medicines for wound healing among tribal people in Southern India; ethnobotanical and scientific evidences introduction. Jour Appl Res in Natural Product. 2009; 2(3):29-42.

2. Bahadur B, Reddy KJ, Rao MLN. Advances in medicinal plants. University Press (India) Private Limited; 2007. p. 1-50.

3. Chaudhari NB, Gokhale SB. Biochemistry and clinical pathology. Nirali Prakashan. 1991. p. 72-7.

4. Chopda MZ, Mahajan RT. Wound healing plants of Jalgaon district of Maharashtra state, India. Ethnobotanical leaflets. 2009; 13:1-32.

5. Chopra RN, Nayar SL, Chopra IC. Glossary of Indian Medicinal plants. New Delhi: CSIR; 1956.

6. Deb AC. Concepts of biochemistry. 2nd ed. Calcutta: Book and Allied Pvt Ltd; 2004. p. 300-24.

7. Dey PM, Harborne JB. Plant biochemistry. Academic Press, A Harcourt Science and Technology Company; 1997. p. 387-416.

8. Hamerski L, Furlan M, Silva DHS, Caralhiera AJ, Eherlin MN, Tomazela D, Bolzani VS. Iridoid glycosides from Randia spinosa (Rubiaceae). Phytochemistry. 2003; 63(4):397-400.

9. Hsu CC, Dobberstein RH, Bingel AS, Fong HHS. Biological and phytochemical investigation of plants Strumpfia maritima. Jour Pharma Sci. 1981; 70(6):682-3.
10. Kannan M, Ranjitsingh AJA, Narayanan M. Phytochemistry and ethnopharmacological studies in Rubia cordifolia L. Ethnobotanical Leaflets. 2009; 13:338-42.

11. Markham R. A steam distillation apparatus suitable for microkjeldahl apparatus. Biochem J. 1942; 36:790-1.

12. Merlin NJ, Parthasarathy V, Manavalan R, Kumaravel S. Chemical investigation of aerial parts of Gmelina asiatica $\mathrm{L}$ by GC-MS. Pharmacognosy Research. 2009; 1(3):152-6.

13. Prasad K, Bisht G. Evaluation of nutritive, antioxidant and mineral composition of Pavetta indica L leaves. Res J Phytochemistry. 2011; 5:54-9.

14. Sanchez JLM. Nitrogen, phosphorus resorption in a neotropical rain forest of a nutrient rich soil. Int J Trop Biology. 2005; 53(3-4):353-9.

15. Siddhuraju R, Becker K. Antioxidant properties of various solvent extracts of total phenolic constituents from three different agroclimatic origins of Drumstick tree (Moringa oleifera Lamar.) leaves. J Agri Food Chemistry. 2003; 51:2144-55.

16. Siddhuraju R, Manian S. The antioxidant activity and free radical scavenging capacity of dietary phenolic extracts from horsegram (Macrotyloma uniflorum (Lamar) Verde) seeds. Food Chemistry. 2007; 105:214-55.

17. Tandon HLS. Methods of analysis of soils, plants, water, fertilizers. New Delhi, India: Fertilizers Development and Consultation Organization; 1993. p. 144.

18. Zhishen J, Mengcheng T, Jianming W. The determination of flavonoid contents in mulberry and their scavenging effects on superoxide radicals. Food Chemistry. 1999; 64:555-9. 